\title{
RESPON PENGGUNAAN FAKTOR PRODUKSI PADA USAHATANI PADI GOGO
}

\author{
(INPUT PRODUCTION USAGE RESPONSE IN DRYLAND PADI \\ FARMING)
}

\author{
Aliudin \\ Fakultas Pertanian Universitas Sultan Ageng Tirtayasa \\ alicardan@yahoo.com
}

\begin{abstract}
Conversion of agricultural land to non agricultural land can not be avoided, while the needs of rice continues to grow. To meet these needs, efforts to develop upland rice are needed. Upland rice can be grown on dry land, moor, or former forest land with minimal irrigation (rainfed). In general, farmers use the production factors uncontrolable, making it difficult to estimate the response of the use of production factors. Based on the research conducted in Cimarga Subdistrict Lebak District in 2010 plant season. This study aims to estimate the response of factors use on upland rice production. Thirty upland paddy farmers were selected using Simple Random Sampling dan Cobb Douglas Model of upland paddy production was applied to analyse production factors response. The results showed: (a) a partial response acreage and volume of urea fertilizer on upland paddy farming is positive, while the number of labor and seed volume showed a negative effect (b) Simultaneously the four factors of production toward upland paddy production has a positive effect. Seed acreage and volume showed a positive response to the production of upland rice indicate that farmers still have a chance to increase acreage and seed use. On the contrary, the use of labor and fertilizer urea showed a negative response indicating that the use of these two production factors have already excessively, and farmers have to reduce the use of these production factors.
\end{abstract}

Key words : production factors, farming, paddy of dry land

\section{PENDAHULUAN}

Pengembangan padi gogo merupakan salah satu strategi positif guna meningkatkan produksi beras menuju kedaulatan pangan nasional. Saat ini, sebagian besar petani menanam padi gogo dengan teknik budidaya yang belum optimal (Wahyuni, et al,1999). Petani padi gogo menanam varietas lokal yang berdaya hasil rendah dan menggunakan benih produksi sendiri dari hasil panen pertanaman musim hujan tahun sebelumnya (Wahyuni et al, 1999). Petani di lapangan dalam penggunaan faktor produksi cenderung tanpa control. Petani 
bebas menggunakan, menentukan, dan mengkombinasikan penggunaan faktor produksi. Kebebasan penggunaan faktor produksi tersebut menyebabkan penggunaan faktor produksi kurang respons terhadap hasil atau lebih dari itu penggunaan faktor produksi tersebut responsnya sudah mengalami kejenuhan. Hal tersebut disebabkan individu-individu petani mempunyai kemampuan (sumberdaya dan pengetahuan) berbeda dan menghadapi lingkungan fisik, sosial dan ekonomi yang beragam, sehingga tingkat adopsi teknologi produksi yang berbeda-beda (Djauhari, 1999). Apabila hal tersebut terjadi ditingkat petani, petani akan mengalami kerugian. Berdasarkan hasil penelitian terdahulu perspektif alih teknologi dan pemahaman teknologi, petani gurem dan penyakap, yang jumlahnya mencapai lebih dari $65 \%$ petani padi dijawa berada pada posisi yang kurang menguntungkan. Pemahaman teknologi budidaya padi oleh petani yang hingga kini masih bersifat empiris perlu ditingkatkan menjadi pemahaman rasional (Sumarno, et al, 2010). Pemahaman rasional tersebut yang harus dikuasai petani adalah efisiensi penggunaan faktor produksi dan berbagai kombinasi alternatif penggunaan faktor produksi yang mampu memberikan total produksi yang optimal.

Provinsi Banten merupakan salah satu penyumbang produksi padi yang signifikan bagi pencapaian sasaran produksi nasional. Pada tahun 2008 produksi padi di Provinsi Banten mencapai 1.710 .849 ton. Pada tahun 2009 produksi padi di Provinsi Banten naik menjadi 1.849.008 ton. Pada tahun 2010 naik menjadi 2.048.152 ton (kenaikannya, 199.144 ton). Pada tahun 2011 produksi padi menurun menjadi 1.953 .505 ton (penurunannya 94.647 ton). Produksi padi tersebut sebagian besar ditanam oleh petani dengan sistem monokultur pada lahan sawah, sebagian yang lain dihasilkan dilahan huma, tadah hujan baik baik dengan sistem monokultur, tumpang sari ataupun dengan sistem sorjan.

Peningkatan produksi padi ini sangat dipengaruhi oleh peningkatan luas panen padi yang signifikan baik untuk padi sawah maupun padi ladang. Luas panen padi sawah tahun 2010 meningkat 35,23 ribu hektar atau naik 10,59 persen, sedangkan luas panen padi ladang meningkat 5,04 ribu hektar atau naik 15,11 persen dibandingkan luas panen tahun 2009. Angka produksi ramalan pada tahun 2011 terjadi penurunan disebabkan oleh penuruanan luas tanam dan serangan hama wereng (Bapenas, 2010).

Salah satu peluang untuk meningkatkan produksi padi di Provinsi Banten adalah dengan mengembangkan padi gogo. Wilayah yang cukup potensial adalah diwilayah Kabupaten lebak. Kabupaten Lebak merupakan lumbung pangan padi di Provinsi Banten, dengan sistem budidaya padi gogo, masyarakat setempat menyebutnya padi ladang. Kecamatan Cimarga yang terletak di wilayah Kabupaten Lebak bagian tengah mempunyai luas wilayah 17.540 ha, yang terdiri dari lahan sawah seluas $1.318 \mathrm{ha}$, dan lahan kering seluas 16.222 ha (Potensi Kecamatan Cimarga, 2010) . Kondisi topografinya sendiri di Kecamatan Cimarga adalah bergelombang dengan ketinggian berkisar antara $30-80 \mathrm{~m}$ dpl dengan tipe iklim B dengan rata-rata curah hujan mencapai $127 \mathrm{~mm}$ dengan jumlah hari hujan 110 hari. 
Padi gogo di Kecamatan Cimarga, diusahakan oleh petani pada lahan kering, dengan pola monokultur. Sistem tanam serempak karena budidaya padi gogo hanya mengandalkan air hujan, sedangkan penggunaan faktor produksinya berbeda diantara petani. Hal tersebut disebabkan oleh variasi modal dan penguasaan teknologi yang berbeda diantara petani. Berdasarkan hal tersebut diperlukan pengkajian terhadap respons penggunaan faktor produksi terhadap hasil produksi padi gogo.

\section{METODOLOGI PENELITIAN}

Metode yang digunakan dalam penelitian ini adalah metode survey. Populasi yang akan disurvai adalah petani yang membudidayakan padi gogo pada musim tanan 2010. Penelitian dilakukan di Kecamatan Cimarga Kabupaten Lebak Provinsi Banten. Waktu penelitian selama 8 bulan tepatnya dimulai Bulan Januari 2011 sampai dengan Agustus 2011. Pemilihan lokasi tersebut dilakukan secara purposive. Alasan pemelihan lokasi tersebut didasarkan pada : (1) Kecamatan Cimarga merupakan Kecamatan yang memiliki karakteristik lahan tanaman padi berupa lahan kering, (2) Petani dikecamatan Cimarga sudah terpola dengan menanam padi gogo secara monokultur,sedangkan di Kecamatan lain di Kabupaten Lebak tanaman padi gogo bersifat sporadis (tidak dalam bentuk hamparan) serta pola tanam yang digunakan dengan sistem diversifikasi.

Metode penarikan sampel yang digunakan simple random sampling. Populasi terdiri dari 120 petani, dipilih 30 petani. Penggunaan teknik sampling ini didasarkan pada pemikiran bahwa setiap stratum populasinya relatif homogen. Tingkat homogenitas tersebut dapat dilihat dari jenis pupuk yang digunakan, jenis benih, teknologi pengolahan lahan

Penelitian ini menggunakan model analisis fungsi produksi CobbDouglas. Fungsi Cobb-Douglas dalam penelitian ini digunakan untuk mengetahui pengaruh faktor produksi pada usahatani padi gogo. Model ini dipilih berdasarkan pertimbangan : (1) Model fungsi Cobb-Douglas adalah Model yang lazim digunakan dalam penelitian ekonomi pertanian karena sifatnya yang praktis dan mudah ditransformasikan ke dalam bentuk linier (Soekartawi, 2003). (2) Menurut Gujarati (2001) koefisien regresi yang ditunjukkan oleh fungsi produksi Cobb-Douglas merupakan elastisitas faktor produksi dan memberikan informasi mengenai respons penggunaan faktor produksi terhadap hasil produksi

Bentuk fungsi produksi Cobb-Douglas adalah sebagai berikut :

$$
\mathrm{Y}=b_{o} x_{1}^{b 1} x_{2}^{b 2} x_{3}^{b 3} x_{4}^{b 4} E^{U}
$$

Jika model tersebut ditransformasikan ke dalam bentuk linier maka formulasi matematisnya akan berbentuk :

$\operatorname{Ln} Y=\ln b o+b_{1} \ln X_{1}+b_{2} \ln X_{2}+b_{3} \ln X_{3}+b_{4} \ln X_{4}+u$, 
dengan ketentuan $Y$ adalah Total produksi padi gogo(ton), $X_{1}$ adalah Luas tanam (ha), $X_{2}$ adalah Volume benih $(\mathrm{kg}), X_{3}$ adalah Penggunaan tenaga kerja (HKP), $\mathrm{X}_{4}$ adalah Pupuk Urea, $\mathrm{b}_{1}-\mathrm{b}_{3}$ adalah Parameter yang akan diduga, $\mathrm{u}$ adalah faktor pengganggu, dan $\mathrm{b}_{0}$ adalah intercept.

Tingkat efisiensi penggunaan faktor produksi dapat dilihat pada nilai bi. Menurut pendapat Cramer, W. Jensen, dan Southgate Jr (2001), bi merupakan indeks efisiensi yang mencerminkan hubungan antara kuantitas produksi dengan seluruh faktor produksi. Tingkat efisiensi penggunaan input produksi dapat dilihat dari optimalisasi penggunaan faktor produksi. Analisis efisiensi faktor produksi yang digunakan dalam usahatani padi gogo melalui pendekatan produk marginal. Pendekatan ini diperoleh dengan membandingkan tiap nilai produk marginal dengan harga input dengan ketentuan nilainya harus sama dengan satu. Formulasinya sebagai berikut:

$$
\frac{N P M_{X 1}}{H x_{1}}=\frac{N P M x_{2}}{H x_{2}}=\frac{N P M x_{3}}{H x_{3}}=1
$$

dimana NPM adalah Nilai Produk Marginal, dan Hx adalah Harga Input.

Nilai Produk Marginal (NPM) dapat dihitung dengan rumus :

$$
N P M=\frac{b i x y}{x i} x H y,
$$

dengan ketentuan bi adalah koefisien regresi atau elastisitas produksi, Hy adalah harga satuan produksi, y adalah hasil produksi, xi adalah faktor produksi ke-i, dan i adalah $1,2,3, \ldots \ldots \ldots \ldots . . . n$.

Apabila rasio nilai produk marginal dengan harga $=1$, berarti usaha agroindustri gula aren cetak sudah efisien, rasio $<1$ tidak efisien dan rasio $>1$ belum efisien (Debertin, 1986).

\section{HASIL DAN PEMBAHASAN}

\section{Karakteristik Responden}

Sebagian besar petani yaitu 23 orang berpendidikan SD, 5 orang berpendidikan SLTP, dan 2 orang berpendidikan SLTA. Luas kepemilikan lahan berkisar antar 0,3-1 ha. Status lahan milik sendiri. Pengalaman petani berusahatani padi gogo rata-rata lebih dari 15 tahun. Teknologi budidaya padi gogo diperoleh secara turun temurun. Responden mengenal teknologi budidaya terutama dlam pemupukan diperoleh dari Penyuluh pertanian atau dari rekan sesame petani. Petani berusahatani padi gogo atas motivasi memenuhi kebutuhan pangan beras bagi keluarga atau dijual apabila produksi berlebih atau kebutuhan terhadap uang tunai mendesak.

\section{Teknik Budidaya}

Budidaya padi gogo sebagian besar menggunakan tenaga kerja keluarga. Teknik budidaya padi gogo dilokasi penelitian dibagi kedalam 4 kegiatan: (1) 
kegiatan membuka lahan (2) kegiatan pengolahan tanah (3) Kegiatan penanaman (4) kegiatan pemeliharaan, dan (5) kegiatan panen dan pasca panen.

Kegiatan membuka lahan; Kegiatan membuka lahan merupakan kegiatan yang dilakukan petani untuk membersihkan lahan dari tumbuhan semak belukar melalui pembabatan, pengeringan dan pembakaran. Pekerjaan ini dilakukan petani menjelang musim hujan. Kegiatan pengolahan tanah; pengolahan tanah yang dilakukan petani sangat sederhana (system olah tanah minimum), petani melakukan pencangkulan sekali dan membiarkan tanah tersebut minimal dua minggu sebelum tanam. Kegiatan penanaman ; kegiatan penanaman dilakukan dengan sistem tabela (tanam benih langsung) dengan jarak tanam yang bervariasi antara $22 \mathrm{~cm} \times 22 \mathrm{~cm}$ sampai dengan $25 \mathrm{~cm} \times 25 \mathrm{~cm}$. Pelobangan dilakukan dengan menggunakan tugal. Benih yang ditanam merupakan benih yang diproduksi sendiri ( hasil padi yang disisihkan tersendiri pada saat panen).

Kegiatan pemeliharaan; kegiatan pemeliharaan yang dimaksud adalah pembersihan tanaman dari rumput dan pemupukan, pemupukan yang terpenting bagi petani adalah pupuk urea, sedangkan pupuk lain digunakan seperlunya, dan hanya beberapa petani saja yang menggunakan pupuk lengkap. Kegiatan panen dan pasca panen: panen dilakukan setelah padi masak umur panen berkisar antara 3,5 bulan sampai 4 bulan. Panen dengan menggunakan ani-ani (alat pemotong padi), dengan sistem pocongan. Panen biasanya dilakukan oleh tenaga kerja luar keluarga adan atau dalam keluarga dengan dengan system upah 5-1 (apabila pemanen dapat lima pocong, maka bagian yang diterima pemanen 1 pocong padi. Setelah panen selesai, dilakukan penjemuran. Penjemuran dilakukan oleh petani dengan mendudukan pocongan padi dalam rentangan bambu sampai padi mongering. Padi yang mengering disusun rapi dalam lumbung padi. Petani sudah terpolakan menyimpan terlebih dahulu padi hasil panen sebelum menjual atau mengolahnya menjadi beras.

\section{Elastisitas Produksi}

Hipotesis yang pertama dalam penelitian ini adalah penggunaan faktor produksi pada usahatani padi gogo tidak respons terhadap hasil produksi. Berdasarkan hasil analisis regresi dari data yang diperoleh bahwa koefisien regresi masing-masing variabel independen disajikan pada Tabel 2.

Berdasarkan Tabel 2. nilai elastisitas produksi yang terbesar adalah luas tanam padi gogo yaitu 0,95. Nilai elastsitas tersebut menunjukkan setiap penambahan luas tanam 1 ha akan meningkatkan produksi 0,95 ton gabah kering panen . Nilai elastisitas produksi untuk tenaga kerja adalah $-0,23$, nilai elastisitas tersebut menunjukkan bahwa setiap penambahan $1 \mathrm{HKP}$ tenaga kerja akan menurunkan produksi 0,23 ton gabah kering panen. Nilai elastisitas produksi penggunaan benih yaitu 0,14 , Nilai elastisitas tersebut menunjukkan setiap penambahan $1 \mathrm{~kg}$ benih akan meningkatkan produksi 0,14 ton gabah kering panen. 
Tabel 2. Nilai Elastisitas Produksi pada Usatani Padi Gogo di Kecamatan Cimarga, 2010

\begin{tabular}{lcc}
\hline \multicolumn{1}{c}{ Variabel } & $\begin{array}{c}\text { Nilai Elastisitas Produksi } \\
\text { (Koefisien Regresi) }\end{array}$ & $\mathrm{t}$ - hitung \\
\hline Luas tanam $\left(\mathrm{X}_{1}\right)$ & 0,95 & 5,42 \\
Volume benih $\left(\mathrm{X}_{2}\right)$ & 0,14 & 0,75 \\
Penggunan Tenaga kerja $\left(\mathrm{X}_{3}\right)$ & $-0,23$ & $-0,56$ \\
Penggunaan pupuk urea $\left(\mathrm{X}_{4}\right)$ & $-0,30$ & $-1,12$ \\
Intercept $\left(\mathrm{b}_{\mathrm{o}}\right)$ & 8,94 & \\
\hline $\mathrm{R}^{2}=0,73$ & & \\
$\mathrm{~F}_{\text {hitung }}=16,66$ & & \\
\hline
\end{tabular}

Nilai elastisitas produksi penggunaan pupuk urea yaitu $-0,30$, Nilai elastisitas tersebut menunjukkan setiap penambahan $1 \mathrm{~kg}$ pupuk urea akan menurunkan produksi 0,30 ton gabah kering panen. Berdasarkan analisis elastisitas produksi luas tanam dan penggunaan benih menunjukkan respon yang positif terhadap hasil produksi padi gogo, sedangkan penggunaan tenaga kerja dan pupuk urea menunjukkan respon negatif. Respon positif dari penggunaan luas tanam dan benih mengindikasikan bahwa petani dapat menambah penggunaan faktor produksi tersebut, karena penambahan kedua faktor produksi masih mampu menambah produksi padi gogo. Respon negatif dari penggunaan tenaga kerja dan pupuk urea mengindikasikan bahwa petani dalam penggunaan tenaga kerja tersebut sudah mengalami titik jenuh, dan penambahan kedua faktor produksi tenaga kerja dan pupuk urea ke dalam proses produksi padi gogo akan mengurangi jumlah produksi padi gogo. Pengurangan tenaga kerja dan pupuk urea dalam nilai riil dapat dikurangi, dan kelebihan dari penggunaan modal untuk tenaga kerja dan penggunaan pupuk dapat didistribusikan untuk menambah faktor produksi yaitu memperluas penanaman atau menambah volume benih.

Pengaruh secara simultan penggunaan faktor produksi pada pada usahatani padi gogo dapat dilihat dari nilai $\mathrm{F}$ hitung yang diperoleh yaitu 16,66 dibandingkan dengan $\mathrm{F}$ tabel 2,44. Hasil analisis regresi menunjukkan bahwa $\mathrm{F}_{\text {hitung }}$ lebih besar dari $\mathrm{F}_{\text {tabel. }}$. Hasil analisis tersebut mengandung arti bahwa input luas tanam, volume benih, tenaga kerja dan penggunaan pupuk urea secara serempak berpengaruh terhadap usahatani padi gogo.

Secara parsial luas tanam $\left(\mathrm{X}_{1}\right)$ berpengaruh nyata terhadap produksi padi gogo, karen nilai $t_{\text {hitung }}(5,42)$ lebih besar dari $t_{\text {tabel }}(2,06)$, sedangkan volume benih $\left(\mathrm{X}_{2}\right)$ yang digunakan tidak berpengaruh nyata terhadap produksi padi gogo karena $t$ hitung $(0,75)$ lebih kecil dari $t_{\text {tabel }}(2,06)$. Tenaga kerja $\left(X_{3}\right)$ tidak berpengaruh nyata terhadap produksi padi gogo karena $t_{\text {hitung }}(-0,56)$ lebih kecil dari $t_{\text {tabel }}(2,60)$. Penggunaan pupuk urea $\left(X_{4}\right)$ tidak berpengaruh nyata terhadap produksi padi gogo karena karena $t_{\text {hitung }}(-1,12)$ lebih kecil dari $t_{\text {tabel }}(2,60)$

Fungsi produksi gula aren cetak di Desa Cimenga secara matematis dapat ditulis sebagai berikut : 
$\operatorname{Ln} Y=\ln 8,94+0,95 \ln X_{1}+0,14 \ln X_{2}-0,23 \ln X_{3}-0,30 \ln X_{4}+\ln \mathrm{e}$

Persamaan di atas dapat ditulis dalam fungsi produksi Cobb-Douglass sebagai berikut:

$$
Y=7.654,13 X_{1}^{0,95} X_{2}^{0,14} X_{3}^{-0,23} X_{4}^{-0,30} e
$$

Berdasarkan nilai elastisitas dapat menjelaskan bahwa faktor produksi yang digunakan dalam usahatani padi gogo yaitu luas tanan dan volume benih yang digunakan sudah memberikan manfaat dan keuntungan karena nilai elastisitas produksi masing - masing input tersebut berada pada tahap rasional (kematangan). Selanjutnya faktor produksi tenaga kerja dan penggunaan pupuk urea tidak memberikan manfaat dan keuntungan karena nilai elastissitas keduanya berada pada tahap jenuh (leveling off). Hal tersebut dapat dilihat dari kisaran nilai elastisitas produksi yang diperoleh di bawah nol $(\mathrm{Ep}<0)$. Apabila dilihat dari nilai elastisitas produksi secara keseluruhan, kondisi usaha kerajinan gula aren cetak berada pada kondisi decreasing rate karena nilainya kurang dari 1 yaitu 0,56.

Koefisien determinasi dari usahatani padi gogo 0,73. Angka ini menunjukkan bahwa faktor produksi luas tanam,volume benih, penggunaan tenaga kerja, dan penggunaan pupuk urea mempengaruhi produksi padi gogo $75 \%$ sedangkan sisanya $27 \%$ dipengaruhi oleh faktor lain yang tidak termasuk dalam variabel penelitian. Faktor lain tersebut yang diduga berpengaruh terhadap produksi padi gogo adalah pengolahan lahan, penggunaan pupuk selain urea, frekuensi penyiangan dan manajemen pengelolaan .

\section{Efisiensi Ekonomi}

Nilai efisiensi penggunaan faktor produksi luas tanam $\left(X_{1}\right)$ dan volume benih yang digunakan $\left(X_{2}\right)$ lebih dari satu, hal ini menunjukkan bahwa penggunaan faktor produksi luas tanam dan penggunaan benih dalam usahatani padi gogo belum efisien . Penggunaan tenaga kerja $\left(X_{3}\right)$ dan volume pupuk urea yang digunakan $\left(\mathrm{X}_{4}\right)$ dalam usahatani padi gogo kurang dari satu, nilai tersebut menunjukkan bahwa penggunaan kedua faktor produksi tersebut tidak efisien. Efisiensi penggunaan faktor produksi usahatani padi gogo di Kecamatan Cimarga dapat dilihat pada Tabel 2.

Nilai efisiensi luas tanam padi gogo $\left(X_{1}\right)$ dan volume benih yang digunakan $\left(X_{2}\right)$, petani pada kondisi tersebut belum dapat menggunakan kedua faktor produksi tersebut dalam jumlah yang optimal, efisiensi akan dicapai apabila petani menambah luas tanam padi gogo dan menambah volume benih. Penggunaan tenaga kerja $\left(X_{3}\right)$ dan pupuk urea $\left(X_{4}\right)$ tidak efisien untuk mengefisienkan penggunaan tenaga kerja dan pupuk urea perlu dikurangi sampai batas tertentu.

Berdasarkan efisiensi ekonomi terdapat kecenderungan, petani kurang mengontrol penggunaan faktor produksi. Penggunaan faktor produksi luas tanam dan volume benih masih respons terhadap peningkatan produksi padi 
gogo karena nilai efisiesi ekonomi lebih besar dari satu. Sebaliknya penggunaan faktor produksi tenaga kerja dan penggunaan pupuk urea sudah tidak merespon terhadap peningkatan produksi padi gogo karena nilai negative (kurang dari satu).

Tabel 2. Efisiensi Penggunaan Faktor Produksi Kerajinan Pada Usahatani Padi Gogo Di Kecamatan Cimarga, 2010

\begin{tabular}{lcrrrr}
\hline \multicolumn{1}{c}{ Faktor Produksi } & Satuan & $\begin{array}{r}\text { Produksi } \\
\text { Marginal }\end{array}$ & $\begin{array}{c}\text { Nilai Produksi } \\
\text { Marginal (Rp) }\end{array}$ & $\begin{array}{c}\text { Harga Faktor } \\
\text { Produksi (Rp) }\end{array}$ & $\begin{array}{r}\text { Efisiensi } \\
\text { Ekonomi }\end{array}$ \\
\hline Luas Tanam $\left(X_{1}\right)$ & ha & 1592,33 & $398.082 .656,00$ & 500.000 & 796,17 \\
Benih $\left(X_{2}\right)$ & $\mathrm{kg}$ & 3,27 & $817.425,68$ & 30.000 & 27,25 \\
Tenaga Kerja $\left(X_{3}\right)$ & $\mathrm{HKP}$ & $-4,46$ & $-1.113 .975,00$ & 30.000 & -37.13 \\
Pupuk Urea $\left(\mathrm{X}_{4}\right)$ & $\mathrm{kg}$ & $-4,07$ & $-1.017 .144,00$ & 1.800 & -565.08 \\
\hline
\end{tabular}

Keterangan : $\mathrm{HKP}=$ Hari Kerja Setara Pria, Harga faktor produksi merupakan harga yang berlaku di lokasi penelitian

\section{SIMPULAN DAN SARAN}

\section{Simpulan}

1. Berdasarkan hasil analisis menunjukkan luas tanam dan penggunaan benih menunjukkan respon yang positif terhadap hasil produksi padi gogo, sedangkan penggunaan tenaga kerja dan pupuk urea menunjukkan respon negatif.

2. Penggunaan luas tanam dan dan volume benih belum efisiensi, sedangkan penggunaan tenaga kerja dan volume pupuk urea yang digunakan dalam usahatani padi gogo tidak efisien.

\section{Saran}

1. Untuk meningkatkan produksi padi gogo, petani dianjurkan untuk memperluas areal tanam dan menambah volume benih, alternatif lain mengontrol jarak tanam yang selama ini digunakan dengan jarak tanam anjuran yang sudah teruji pengaruhnya terhadap hasil produksi, mengganti benih padi gogo, yang selama ini menggunakan hasil benih sendiri dengan varietas benih unggul.

2. Mengurangi dan mengontrol penggunaan tenaga kerja dan volume pupuk urea. Biaya yang dikeluarkan untuk membayar tenaga kerja dan biaya yang dikeluarkan untuk membeli pupuk urea dapat digunakan untuk menambah biaya yang lain, alternatif yang dapat dilakukan oleh petani yaitu mencurahkan biaya tersebut untuk membeli pupuk lain 
(pupuk kandang, TSPdan KCL) atau dicurahkan untuk pemeliharaan (penyiangan dan pestisida), di tingkat petani pemakaian faktor produksi pupuk kandang, TSP, KCL sangat minimal, begitupun tenaga kerja yang tercurah untuk penyiangan.

3. Untuk menghemat dan mengefisienkan penggunaan faktor produksi usahatani padi gogo dianjurkan untuk membentuk dan memberdayakan petani dalam bentuk kelompok, hal ini dilakukan untuk menekan biaya per unit faktor produksi, sehingga pengeluaran di tingkat petani dapat diminimalisir.

\section{DAFTAR PUSTAKA}

Badan Pusat Statistik, 2010. Banten Dalam Angka. BPS Provinsi Banten. Banten.

Bapenas, 2010. Laporan Evaluasi Kinerja Pembangunan Provinsi Banten. BapenasUniversitas Sultan Ageng Tirtayasa. Banten.

Cramer, Gail L., W. Jensen, Clarence, dan Southgate Jr, Douglas D, 2001. Agricultural Economic and Agribusiness. John Wiley and Sons, Inc. New York. Chichester, Weinheim ,Brisbane, Singapore dan Toronto.

Debertin, David. 1986. Agricultural Production Economics. Macmilan Publishing Company New York, Coller Mac Millan Publishers London, University of Kentucky, USA.

Djauhari, Aman, 1999. Pendekatan Fungsi Cobb-Douglas dengan Elastisitas Variabel dalam Studi Ekonomi Produksi Suatu : Contoh Aplikasi pada Padi Sawah. Jurnal Informatikan Pertanian 8:. Desember 1999.

Sri Wahyuni, Triny S. Kadir, Udin S. Nugraha. 2006. Hasil dan Mutu Benih Padi Gogo pada Lingkungan Tumbuh Berbeda. Jurnal Balai Penelitian Tanaman Padi 25(1): . Bogor

Statistik Kecamatan Cimarga, 2010. Potensi Kecamatan Cimarga. CimargaLebak-Banten.

Sumarno, U.G. Kartasasmita, dan Lukman Hakim, 2010. Pengelolaan Lahan Sawah dan Reorientasi Target Alih Teknologi Usahatani Padi di Jawa. Jurnal Iptek Tanaman Pangan. Pusat Penelitian dan Pengembangan Tanaman Pangan. Badan Penelitian dan Pengembangan Pertanian. Bogor.

Soekartawi,2003. Teori Ekonomi Produksi dengan Pokok Bahasan Analisis Fungsi Cobb Douglas. Penerbit PT. Raya Grafindo Persada, Jakarta.

Gujarati, Damodar 2001. Ekonometrika Dasar. Erlangga. Jakarta. 